\section{IN brief}

\section{Genzyme takes Campath bet}

Genzyme has shored up its oncology and multiple sclerosis franchise through a new deal with Bayer, of Leverkusen, Germany. Best known for targeting rare genetic disorders, Genzyme is bringing into its stable three approved cancer therapeutics: Fludara (fludarabine) for B-cell chronic lymphocytic leukemia (B-CLL); Leukine (sargramostim), a hematopoietic growth factor used to stimulate the bone marrow following chemotherapy; and Campath (alemtuzumab) for B-CLL. The Cambridge, Massachusetts, company will pay up to $\$ 500$ million (plus another $\$ 150$ million after 2011) based on annual revenues, for those three products. Bayer will continue to supply Fludara and Leukine, although Genzyme is acquiring a Leukine-manufacturing plant for $\$ 75$ million to $\$ 100$ million and will produce that product itself when the plant is cleared by the US Food and Drug Administration. Perhaps the most interesting aspect of the deal is that Campath is being tested against multiple sclerosis (MS). The companies have been linked over Campath since 2006, but this deal transfers all marketing rights to Genzyme while Bayer continues to support development. Campath, a humanized monoclonal antibody that binds to CD52, has shown promise in phase 2 trials for MS, and is currently in two phase 3 trials. If approved for MS, Bayer could receive up to $\$ 1.25$ billion, plus further payments related to sales after 2021 (Genzyme retains a buyout option for Bayer's share in 2020 for $\$ 900$ million). Although Bayer could still co-promote the drug in the US, Genzyme now has primary responsibility in MS. But don't let the high milestone payments deceive-all those moving parts in essence mean the deal is more about "altering accounting and delineating development responsibilities" rather than making a strategic shift for Genzyme, says Brian Abrahams, analyst with Oppenheimer in New York. Brady Huggett

\section{New product approvals}

\section{Removab (catumaxomab)/Trion Pharma} (Munich)/Fresenius (Homburg, Germany)

The European Commission on April 23 approved Removab, a new-generation trifunctional antibody, to treat malignant ascites common in ovarian, pancreatic and gastric cancers. The antibody possesses two different antigen binding sites: one targets the human epithelial cell adhesion molecule (EpCAM), which is found in the majority of epithelial tumors, the other targets human CD3 on T-lymphocytes.

\section{Simponi (golimumab)/Johnson \& Johnson (New} Brunswick, New Jersey)

The US Food and Drug Administration on April 24 approved Simponi, a secondgeneration tumor necrosis factor- $\alpha$ inhibitor, to treat three forms of arthritis. Simponi is a once-monthly subcutaneous injection for treating adults with moderate to severe rheumatoid arthritis, active psoriatic arthritis and active ankylosing spondylitis. points to a clause in the guidance that recommends sponsors "consult with FDA concerning the regulatory pathway for the use of cell selection devices.” Regarding any developments that might have prompted the guidance, Cruzan says that the agency "wouldn't be able to comment on the safety risks observed in trials performed thus far, due to confidentiality regulations or anything under an [investigational new drug application]."

In all cardiac cell therapy, maintaining purity, potency, identity, sterility and shelf life-all elements of cell therapeutics as called for in the guidance-is the key to a regulatory win, along with proving what the mechanism of action is, said Andrew L. Pecora, chairman of Amorcyte's board, a company based in Hackensack, New Jersey, that has recently released phase 1 results of an autologous stem cell treatment for heart muscle damaged by infarcts. Pecora claims the overall task is not as difficult as it seems. "If I'm going to squirt cells through a threefoot catheter into your heart, you want to know they're going to be okay when they come out the other end. There are some very simple things [to determine], that is, is your project sterile? Is it pure? Some areas are going to be fairly easy," whereas others will be more challenging, such as batch-release specifications for each autologous group of cells. "Instead of having one huge batch in a vat, with cell therapy, it's going to be realtime delivery. There's an infrastructure that's different from [work typically done by] the biotech or pharmaceutical industry."

One thing seems clear: the agency intends to classify cell therapies as combination products. The FDA's Center for Biologics Evalution and Research "would be the lead division and consult with the device group," called the Center for Devices and Radiological Health (also FDA). "In the small-molecule world, this happens as well," says Wolin-and it adds an extra hurdle. More daunting, perhaps, are the requirements for cell therapy manufacture. "Several animal studies and/or species may be necessary to adequately model functional aspects and potential toxicities of a single product," the draft says, but how many will be required will depend on the "biological characteristics of the product," a point likely to be argued over.

Each cell-therapy company will have its own conversation with regulators, says Paul J. Schmitt, acting CEO of Amorcyte. Schmitt lauded the draft guidance, saying the field "needs to progress from outstanding science to the rigors of real drug development," a move that would "start to take the charlatans out of the industry."

Randy Osborne Mill Valley, California

\title{
India's first true stem cell trials
}

The Drug-Controller General of India (DCGI) has given the go-ahead for the first clinical trials designed to test stem cell products. Stempeutics Research of Bangalore launched a combined phase 1 and phase 2 trial on April 22 to evaluate whether its stem cell products can benefit people who have experienced myocardial infarction and individuals with critical limb ischemia (CLI)—a condition that often requires amputation.

"These are the only two stem cell trials officially approved to date," says Polani B. Seshagiri, a member of a government panel that made the recommendation to DCGI. There have been many claims in the past from Indian labs offering stem-cell therapy to treat a wide range of diseases, prompting criticisms that local regulators were failing to monitor the procedures (Nature 434, 259, 2005). But Seshagiri, who heads the Stem Cell and Transgenic Research Lab at the Indian Institute of Science in Bangalore, says, "none of these can be called a clinical trial." The Stempeutics trials are the first randomized, double-blind, multicentric, placebo-controlled studies. Each trial will recruit 100 patients in batches.

"Our goal is to bring out affordable stem cell-based products as drugs in chemists' shops," says Stempeutics' president Balu N. Manohar. The company extracts mesenchymal stem (MS) cells from the bone marrow of healthy donors and expands them in culture before infusing them back in. These MS cells are well tolerated by the recipient because they lack immunogenic major histocompatibility complex class II molecules on their surface, says Ramesh Bhonde, technical director for Stempeutics. The company has scaled up the production process to obtain 300 to 400 million MS cells of good manufacturing practice quality from a single donor. Preclinical animal toxicity studies, says Bhonde, confirm that ex vivo cultured adult MS cells are safe and can be used both in autologous and allogenic settings. Seshagiri does not expect any major obstacles in this form of therapy as long as the cells are clinical grade.

Killugudi Jayaraman, Bangalore, India 